\title{
Customer orientation and financial performance relationship: the mediating role of innovative capability
}

\section{A relação entre a orientação ao cliente e o desempenho financeiro: o papel mediador da capacidade de inovação}

\author{
Mirela Jeffman dos Santos ${ }^{1}$, Marcelo Gattermann Perin² (1), Cláudia Simões ${ }^{3}$, \\ Cláudio Hoffmann Sampaio ${ }^{4}$ \\ ${ }^{1}$ Universidade de Santa Cruz do Sul - UNISC, Programa de Pós-graduação em Administração, Santa Cruz do Sul, \\ RS, Brasil. E-mail: mirelajs@unisc.br \\ ${ }^{2}$ Fundação Getulio Vargas - FGV, Escola de Administração de Empresas de São Paulo - EAESP, São Paulo, SP, \\ Brasil. E-mail: mperin25@gmail.com \\ ${ }^{3}$ Universidade do Minho - UMINHO, Escola de Economia e Gestão, Campus de Gualtar, Braga, Portugal. \\ E-mail: csimoes@eeg.uminho.pt \\ ${ }^{4}$ Pontifícia Universidade Católica do Rio Grande do Sul - PUCRS, Programa de Pós-graduação em Administração, \\ Porto Alegre, RS, Brasil. E-mail: csampaio@pucrs.br
}

How to cite: Santos, M. J., Perin, M. G., Simões, C., \& Sampaio, C. H. (2020). Customer orientation and financial performance relationship: the mediating role of innovative capability. Gestão \& Produção, 27(4), e4706. https://doi.org/10.1590/0104-530X4706-20

\begin{abstract}
Existing research establishes customer orientation (CO) per se as insufficient to achieve higher levels of financial performance (FP). Such reasoning suggests the need for additional skills and capabilities, such as, innovative capability (IC). In addition, environmental variables (e.g., Technological Turbulence - TT) affect these relationships. This paper explores the relationships and effects of $\mathrm{CO}$ and IC on FP under different TT conditions. A research framework and hypotheses were developed. The framework captures the following relationships: (i) the direct influence of $\mathrm{CO}$ on FP; (ii) the mediating role of IC on the CO/FP relationship; (iii) the moderating role of TT over the mediation of IC on the CO/FP relationship. The fieldwork included an exploratory stage, followed by a cross-sectional survey applied to managers in medium-sized companies in Brazil. Findings revealed that IC partially mediates the relationship between $\mathrm{CO}$ and FP, in particular in high TT environments. Managerial implications and avenues for future research are presented.
\end{abstract}

Keywords: Customer orientation; Financial performance; Innovative capability; Technological turbulence; Emerging market.

Resumo: A pesquisa existente estabelece que a orientação ao cliente (CO), por si só, é insuficiente para atingir níveis mais elevados de desempenho financeiro (FP). Tal raciocínio sugere a necessidade de habilidades e capacidades adicionais, como a capacidade de inovação (IC). Além disso, as variáveis ambientais (por exemplo, turbulência tecnológica - TT) podem afetar essas relações. Este artigo explora as relações e os efeitos da $\mathrm{CO}$ e da $\mathrm{Cl}$ no FP em diferentes condições de TT, tendo sido desenvolvido um modelo teórico correspondente. Tal modelo envolve as seguintes relações: (i) a influência direta da CO no FP; (II) o papel mediador da IC na relação CO/FP; (III) o papel moderado do TT sobre a mediação da IC na

Received Mar. 15, 2018 - Accepted July 27, 2018

Financial support: None.

This is an Open Access article distributed under the terms of the Creative Commons Attribution License, which permits unrestricted use, distribution, and reproduction in any medium, provided the original work is properly cited. 
relação CO/FP. O trabalho de campo incluiu uma etapa exploratória, seguida de um levantamento transversal aplicado aos gestores de empresas de médio porte no Brasil. Os achados revelaram que a $\mathrm{Cl}$ tem mediação parcial na relação entre CO e FP, em particular em ambientes de alta TT. Implicações gerenciais e sugestões para futuras pesquisas são apresentadas.

Palavras-chave: Orientação ao cliente; Desempenho financeiro; Capacidade de inovação; Turbulência tecnológica; Mercado emergente.

\section{Introduction}

Transformations in the business environment, such as, the emergence of new technologies and changes in customer preferences, call for organizations to develop new market approaches and capabilities (Paladino, 2008; Wei \& Morgan, 2004). The different capabilities and their combination are expected to generate competitive advantage and, ultimately, impact on business survival (Watson et al., 2018). The theory of the Resource Based View (RBV) of the firm posits that the right combination of internal resources fosters the development and implementation of strategies that generate a leading position in the market (Hooley et al., 2001), competitor differentiation and competitive advantage (Barney, 1991). Resource effectiveness emerges from the arrangement of the organization's capabilities that support the application and the use of knowledge created internally (Hooley et al., 2001). Yet, the inertia of stable and common resources may not generate the full potential for competitive advantage, implying new resource arrangements (Eisenhardt \& Martin, 2000). In fact, resources are in permanent transformation (Teece, 2007) and are integrated in the organizations' strategic orientation, consumer/stakeholder relationships and in marketing capabilities that coordinate the resource articulation to the market (Hooley et al., 2001). As a consequence, organizations ought to develop suitable and relevant capabilities that leverage their competence in addressing the market and business environment.

A relevant capability, emerges from the ability that organizations have to assess and collect stakeholder information in order to develop internal capabilities (Watson et al., 2018). For example, Customer Orientation (CO) is a strategic orientation directed at searching, collecting and using information about customers (Atuahene-Gima, 2005). CO is related to the development of a market orientation (Tajeddini, 2010; Frambach et al., 2016) and to the generation of innovation and Financial Performance (FP) (Woodside, 2005). Ultimately, CO may be considered a critical strategic capability (Nakata \& Zhu, 2006) in reaching market success (Booner, 2009). Organizations further need the ability to develop innovations (Saunila et al., 2014 ) to address market dynamics. In particular, organizations endeavor to transform customer knowledge into new products or processes so that market needs are met (Hult et al., 2005; Vorhies et al., 2009). The Innovative Capability (IC) encompasses the organization's ability to generate, create, and develop innovations (Akman \& Yilmaz, 2008). The underlying idea is to use resources and skills to explore market opportunities in a proficient way (Neely et al., 2001). Such capability may be a source of competitive advantage (Akman \& Yilmaz, 2008; Stock \& Zacharias, 2011) and financial development (Saunila et al., 2014), especially in turbulent business environments (Song et al., 2005).

The way organizations combine different capabilities is expected to impact business performance (Watson et al., 2018). The marketing literature addressed $\mathrm{CO}$ as a 
determinant of FP (e.g., Tajeddini, 2010; Theoharakis \& Hooley, 2008). Yet, existing studies about the direct relationship between strategic orientations and FP reveal that strategic orientations per se would not lead to superior performance (e.g., Jeong et al., 2006). In this line of thought, part of these studies reported IC as a mediator of the relationship between CO and FP (e.g., Piening \& Salge, 2015; Cheng \& Krumwiede, 2012; Hortinha et al., 2011). A scarcity of studies further analyzed the moderating role of environmental factors in the relationship between strategic orientations and FP. In particular, Technological Turbulence (TT) represents a set of changes in the environment that increases risks and uncertainties in innovation processes (Calantone et al., 2003). TT may be extremely influential in the innovation process and, consequently, in achieving higher levels of FP (Piening \& Salge, 2015). Accordingly, TT has been addressed as an environmental variable moderating the relationship between IC and FP (e.g., Piening \& Salge, 2015).

This paper explores the relationships and effects of $\mathrm{CO}$ and IC on FP under different TT conditions. In particular, the study addresses the following aspects: (i) the direct influence of $\mathrm{CO}$ on FP; (ii) the mediating of IC on the CO/FP relationship; (iii) the moderating role of TT over the mediation of IC on the CO/FP relationship. The research reports an empirical quantitative study conducted among business managers in Brazil. The paper follows with the presentation of the theoretical background of the study and the development of the research hypotheses. The subsequent sections describe the research design and research findings. The final section includes the discussion and conclusion.

\section{Theoretical background}

The principles of the RBV are widely used in the strategic marketing literature as a foundation for investigating organizational resources that lead to market strength and superior performance (Kozlenkova et al., 2013). The notion of resource is core to the RBV theory and is best captured by the features that resources should entail. In particular, a resource should: add value to the organization (i.e., allow for taking advantage of opportunities and neutralizing external threats); be rare in the market; be hard to imitate; and, be possible to explore through the organization's capabilities (Barney, 1991; Kozlenkova et al., 2013). Organizations use resources to attain their objectives and assure business survival, as they are linked to the formation and implementation of strategies that lead to superior performance (Hooley et al., 2001). Organizations have distinct resources even when operating in the same market segment and they are difficult to transfer among companies. Hence, competitive advantage is maintained because resources are heterogeneous and lack mobility in the market (Barney, 1991).

Competitive advantage further emerges from the effective combination of resources developed internally in the organization and matched by relevant business capabilities (Sanches \& Machado, 2014). A business capability captures the ability that an organization has to apply its resources in an efficient and productive way (Kozlenkova et al., 2013). The capability is a set of strategic routines that enable managers to change their resource base to develop strategies that lead to added value. Such capabilities are developed at a collective level, resulting from the integration of multiple routines, procedures, and behaviors that are built over time within the organization (Eisenhardt \& Martin, 2000). A capability has a higher level of complexity as it is incorporated in the organization's routines and is not easily copied or modified 
(Ngo \& O'Cass, 2012). Different organizations have distinct types of capabilities (Watson et al., 2018). According to RBV, CO and IC are core capabilities that organizations ought to develop (Vargas et al., 2017). Firms with higher CO have a superior capability to improve internal processes and to provide customer value (Yilmaz et al., 2005). IC is a "[...] key driver in management of innovation" (Neely et al. 2001, p. 118).

\subsection{Research framework and hypotheses}

Businesses need skills that enable them to consistently deliver benefits to customers (Booner, 2009). Organizations attain higher performance, not only for having the best resources, but also for having the best skills to apply and use those resources (Sok et al., 2016). Superior performance is achieved by integrating capabilities associated with specific functional areas of the organization, and by promoting greater complementarities (Stock \& Zacharias, 2011). Previous research has addressed the links between $\mathrm{CO}, \mathrm{IC}$ and FP in different ways. Table 1 summarizes the literature addressing those relationships. Studies are more abundant concerning the main effects among CO, IC and FP (e.g., Akman \& Yilmaz, 2008; Piening \& Salge, 2015; Theoharakis \& Hooley, 2008). Although in a scarcer number, environmental conditions regarding TT have also been considered (e.g., Piening \& Salge, 2015).

Table 1. Studies addressing the effects between CO, IC, FP and TT.

\begin{tabular}{|c|c|c|c|c|}
\hline \multirow{2}{*}{ Studies } & \multicolumn{3}{|c|}{ Main Effects } & \multirow{2}{*}{$\begin{array}{l}\text { Moderato } \\
\text { TT }\end{array}$} \\
\hline & $\mathrm{CO} \rightarrow \mathrm{IC}$ & IC $\rightarrow$ FP & $\mathrm{CO} \rightarrow \mathrm{FP}$ & \\
\hline Akman \& Yilmaz (2008) & $\checkmark$ & $\checkmark$ & & \\
\hline Augusto \& Coelho (2009) & $\checkmark$ & & & \\
\hline Calantone et al. (2010) & $\checkmark$ & & & \\
\hline Cheng \& Krumwiede (2012) & $\checkmark$ & & $\checkmark$ & \\
\hline Frambach et al. (2003) & $\checkmark$ & & & \\
\hline Frambach et al. (2016) & $\checkmark$ & & $\checkmark$ & \\
\hline Han et al. (1998) & $\checkmark$ & & & \\
\hline Hortinha et al. (2011) & $\checkmark$ & & $\checkmark$ & \\
\hline Jeong et al. (2006) & & & $\checkmark$ & \\
\hline Joshi (2016) & $\checkmark$ & & & \\
\hline Menguc \& Auh (2010) & & $\checkmark$ & & \\
\hline Piening \& Salge (2015) & & $\checkmark$ & & $\checkmark$ \\
\hline Saunila et al. (2014) & & $\sqrt{ }$ & & \\
\hline Sher \& Yang (2005) & & $\checkmark$ & & \\
\hline Song et al. (2005) & & $\checkmark$ & & $\checkmark$ \\
\hline Tajeddini (2010) & & & $\checkmark$ & \\
\hline Theoharakis \& Hooley (2008) & $\checkmark$ & & $\checkmark$ & \\
\hline Woodside (2005) & $\checkmark$ & & & \\
\hline Yilmaz et al. (2005) & & & $\checkmark$ & \\
\hline
\end{tabular}

This study builds on the idea that relevant business capabilities complement each other. The underlying rationale is that resources must be transformed into added value 
offers to the market (Booner, 2009). The transformation of resources happens through the development of special capabilities like CO and IC (Eisenhardt \& Martin, 2000; Akman \& Yilmaz, 2008). The study's general argument portrays that companies with greater $\mathrm{CO}$ are expected to present support for innovation (IC), market success, and ultimately, higher levels of FP (Woodside, 2005). Environmental variables, such as TT, intervene in these relationships. Figure 1 depicts the theoretical framework and the research hypotheses capturing this argument.

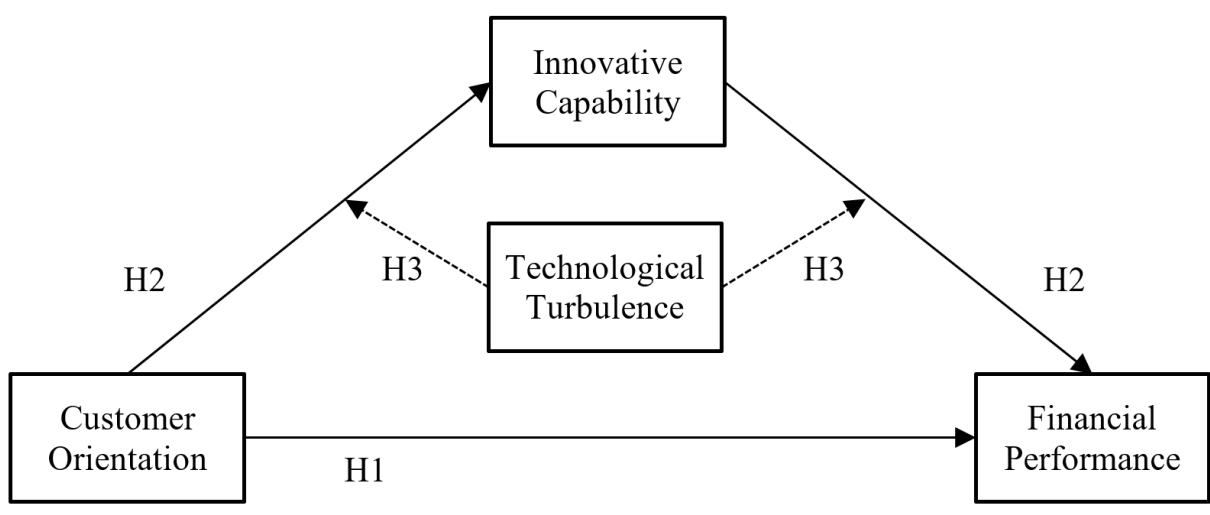

Figure 1. Theoretical framework.

$\mathrm{CO}$ reflects an organization's approach to collect information about current and future customer habits, and to disseminate and use the information within the organization (Atuahene-Gima, 2005; Deluca et al., 2010). A customer-oriented approach involves the proximity of the organization with its customers (Macintosh, 2007). CO covers customer behavior identification, analysis, understanding and responses (Yang et al., 2012; Augusto \& Coelho, 2009). In sum, CO entails the collection of market feedback to comprehensively understand customer behavior (Auh \& Menguc, 2005). CO is manifested through the degree to which an organization and its professionals have contact with customers (Macintosh, 2007) and focuses on obtaining market feedback (Akgün et al., 2010), understanding, and satisfaction (Augusto \& Coelho, 2009; Yilmaz et al., 2005). Customer information reduces uncertainty about the external environment, in particular regarding issues related to customer needs. Updated information about the customer improves decision making efficiency (Van Riel et al., 2004).

$\mathrm{CO}$ is a central component of market orientation and an important driver for firm performance (Kirca et al., 2005). Since CO prioritizes customers' needs, allows for the identification and analysis of customer preferences and, thus, to serve them better (Augusto \& Coelho, 2009; Gao et al., 2007). CO supports organizations in developing innovative projects (e.g., products and services) that better meet customers' needs (Deluca et al., 2010; Grinstein, 2008) generating higher value offers and products in the market. The aim is to assist customers in their buying decisions and to develop offers that best satisfy their needs (Macintosh, 2007). A company can gain an advantage over competitors by focusing its efforts on customer satisfaction (Jeong et al., 2006). CO is reflected in the organizational culture (Menguc \& Auh, 2006) and impacts FP (Nakata \& Zhu, 2006). Frambach et al. (2016, p. 1433) found evidence for the effect of $\mathrm{CO}$ on firm's performance where "[...] customer orientation is 
consistently part of high-performance configurations". Hence, the following hypothesis is proposed:

$\mathrm{H}_{1}$ : Customer orientation positively influences financial performance.

Claims that $\mathrm{CO}$ per se leads directly to higher FP have been challenged due to inconsistent findings regarding the effect of $\mathrm{CO}$ in FP. Such reasoning suggests that $\mathrm{CO}$ alone is not sufficient for the organization to reach higher levels of performance (Booner, 2009). Indeed, a customer oriented approach, although crucial to create an innovative environment (Akman \& Yilmaz, 2008) and compete in the market, seems insufficient to reach an outstanding performance (Booner, 2009). These arguments are supported with findings reporting the absence of and/or an insignificant direct relationship between $\mathrm{CO}$ and performance (e.g., Langerak et al., 2004; Jeong et al., 2006).

The information obtained from customers, needs to be converted into market offers endowed with attributes and features that meet expectations and satisfy the market. Customer knowledge must be harnessed and transformed so that the organization attains higher levels of FP (Piening \& Salge, 2015; Saunila et al., 2014). The transformation of customer based knowledge into tangible results occurs through the development of specific skills (Rijsdijk et al., 2010). Organizations develop distinct capabilities consistently with their environment and innovation activity. It is important to cultivate the capability of learning through stakeholder engagement and embrace different viewpoints. The underlying idea is to create value together with the customer, reformulating problems and proposing innovative solutions (Watson et al., 2018). The endeavor entails an interactive process that starts with identifying an opportunity (a new market and/or new product) and evolves into the development, production and marketing of the new product to the target market (Garcia \& Calantone, 2002). IC translates such organizational capability (Akman \& Yilmaz, 2008). IC involves a set of abilities embracing the organization's culture orientation, the structure, the individual activities and market knowledge (Saunila et al., 2014). That is, IC can be understood as the ability that an organization has to generate results from innovations, using resources and skills in the best possible way, with a view to explore market opportunities (Neely et al., 2001).

The continuous gathering of external (market) knowledge is core for innovation generation, supporting planning and development activities (Piening \& Salge, 2015). Consequently, IC is more likely to occur in firms with greater CO (Joshi, 2016; Han et al., 1998). The focus on customers encourages decisions and management actions driving the development of skills that facilitate the alignment between what is offered in the market, and what customers expect out of these offers (Ngo \& O'Cass, 2012). Consequently, $C O$ instills the continuous update of internal capabilities to better serve customers. Stock \& Zacharias (2011) defend that customer-related information is a strong stimulus for innovation, because it generates new ideas for new product development, supports the delivery of superior value in the market and, ultimately leads to higher FP. Hence, knowledge about the external environment (in particular about customers) is integrated in the capability of the organization to develop innovations (Saunila et al., 2014). Thus, customer-oriented companies are more likely to develop new ideas because they are engaged in an active dialogue with their customers and use their knowledge to identify and respond to market opportunities (Spanjol et al., 2011). Based on this discussion the following hypothesis is derived:

$\mathrm{H} 2$ : IC mediates the impact of customer orientation on financial performance. 
Environmental conditions affect the way companies operate in their markets (Piening \& Salge, 2015). Variables, such as, the industry's structure, complexity, heterogeneity, and turbulence have an impact on the way companies function, directly influencing strategies and decision making (Kuivalainen et al., 2004). When environmental conditions are turbulent and less predictable, organizations tend to adjust their way of working in order to overcome the challenges of such context (Piening \& Salge, 2015). Organizations operating in turbulent environments ensure business survival by seeking an alignment between their internal resources and the external demand (Akgün et al., 2012). Turbulent conditions require internal teams to be committed and dedicated to carry out their roles during innovation development (Dayan \& Elbanna, 2011). Therefore, professionals ought to adjust their actions, practices, and beliefs, adapting to changes more rapidly (Akgün et al., 2012).

Among the environmental turbulence factors, TT stands out as having a strong effect on the internal development of innovation (Buganza et al., 2009). Technological innovations can cause turbulence in the environment, accelerate market changes (Calantone el al., 2003), or lead to new technical discoveries (often causing the implementation of new legal systems) (Akgün et al., 2006). Organizations operating in environments with high TT are exposed to constant advances in technology. Changes may suddenly occur and unexpectedly, rapidly turning existing products obsolete (Lee, 2010). Technologically unstable environments cause risk and uncertainty in innovation development processes because demand forecast is more difficult, and existing products become outdated in shorter periods of time (Rijsdijk et al., 2010). Such context requires the organization to identify technological opportunities created by rapid environmental changes and to timely introduce innovations in the market ( $\mathrm{Li}$ et al., 2008). In this way, uncertainty favors the use of resources and the development of new capabilities (Piening \& Salge, 2015). Ultimately, turbulent environments may lead the organizations to develop a competitive advantage through the creation of capabilities and strategies that are more difficult for competitors to imitate in a timely manner, enhancing market competitive advantage (Barney, 1991). When the business environment is relatively stable and predictable, competitors can more easily capture and imitate the resources that are being used. Conversely, in turbulent environments, organizations tend to use a set of dynamic capabilities, making competitor imitation more difficult, thus positively impacting FP (Song et al., 2005). Hence, in high TT environments, IC is fundamental to the reach higher FP. Hence, the following hypothesis is proposed:

H3: TT positively moderates the indirect effect of $\mathrm{CO}$ and FP - the stronger the TT, the greater the impact of $\mathrm{CO}$ on FP through IC.

\section{Method}

The empirical study entailed a cross-sectional survey applied to business managers in Brazil. The sample framework included 2,500 medium-sized Brazilian companies withdrawn from the Dun \& Bradstreet database (recent studies have validated the accuracy of Dun \& Bradstreet data; e.g., Baum \& Locke, 2004). The companies had a number of employees within the interval 100 to 499 (IBGE, 2017). The database included firms operating in a wide range of industrial markets (Akgün et al., 2010; Smirnova et al., 2011). As an initial step, general managers of 1.000 firms were contacted by phone and asked to participate in the survey. Among those, 659 agreed to be contacted by email and receive the link to the questionnaire. The sample 
produced 153 usable questionnaires resulting in a response rate of $15.3 \%$. This response is considerably higher than the response rates obtained in studies conducted in developing countries (Sousa \& Lengler, 2009).

The sample included firms from the states of São Paulo (40.1\%), Rio Grande do Sul (16.2\%), Santa Catarina (8.4\%), Paraná (7.8\%) and Rio de Janeiro (6.6\%). In what concerns the companies' country of origin, $79 \%$ are domestic and $21 \%$ are multinationals. Regarding the year when companies started their activity the sample presented the following distribution: about $5.1 \%$ started before $1950 ; 28.7 \%$ in the period 1951 and 1980; $47.1 \%$ from 1981 to 2000; and, $19.1 \%$ after 2000. The organizations' industry was classified using the Standard Industrial Code (SIC). The companies in the sample are mainly concentrated in the fields of manufacturing $(59.9 \%)$ and mining $(39.5 \%)$. The sample has a similar profile to the population of medium-sized companies in Brazil (Table 2).

Table 2. Sample profile.

\begin{tabular}{|c|c|c|c|c|}
\hline$\underline{\text { Variable }}$ & \multicolumn{2}{|c|}{ Population } & \multicolumn{2}{|c|}{ Sample } \\
\hline \multicolumn{5}{|l|}{ Size (number of employees) } \\
\hline & $\mathbf{n}$ & $\%$ & $\mathbf{n}$ & $\%$ \\
\hline $100-200$ & 1.367 & $52.2 \%$ & 91 & $59.5 \%$ \\
\hline $201-300$ & 599 & $22.9 \%$ & 28 & $18.3 \%$ \\
\hline $301-400$ & 390 & $14.9 \%$ & 15 & $9.8 \%$ \\
\hline more than 400 & 264 & $10.1 \%$ & 19 & $12.4 \%$ \\
\hline Total & 2.620 & & 153 & \\
\hline \multicolumn{5}{|l|}{ Year the company was created } \\
\hline & $\mathbf{n}$ & $\%$ & $\mathbf{n}$ & $\%$ \\
\hline Before 1900 & 6 & $0.2 \%$ & 1 & $0.7 \%$ \\
\hline $1901-1950$ & 138 & $5.3 \%$ & 7 & $4.6 \%$ \\
\hline $1951-1980$ & 815 & $31.1 \%$ & 46 & $30.1 \%$ \\
\hline $1981-2000$ & 1.258 & $48.0 \%$ & 75 & $49.0 \%$ \\
\hline After 2000 & 403 & $15.4 \%$ & 24 & $15.7 \%$ \\
\hline Total & 2.620 & & 153 & \\
\hline \multicolumn{5}{|l|}{ Industry } \\
\hline Standard Industrial Code (SIC) & $\mathbf{n}$ & $\%$ & $\mathbf{n}$ & $\%$ \\
\hline Agriculture & 14 & $0.5 \%$ & 1 & $0.7 \%$ \\
\hline Construction & 10 & $0.4 \%$ & 0 & $0.0 \%$ \\
\hline Utilities & 4 & $0.2 \%$ & 0 & $0.0 \%$ \\
\hline Manufacture & 1.651 & $63.0 \%$ & 94 & $61.4 \%$ \\
\hline Mining & 939 & $35.8 \%$ & 58 & $37.9 \%$ \\
\hline Transportation and Communications & 2 & $0.1 \%$ & 0 & $0.0 \%$ \\
\hline Total & 2.620 & & 153 & \\
\hline
\end{tabular}

Population represents the Dun \& Bradstreet database summary. Column $\mathbf{n}$ indicates the number of cases.

\subsection{Questionnaire development and testing}

The scales used in the questionnaire were grounded on existing measurements taking into account the research context. Considering that the operationalization of IC is complex (Martínez-Román et al., 2011) the fieldwork entailed 7 preliminary semi-structured 
interviews with innovation managers. The aim was to ascertain whether the existing scale would reflect the construct in the context of the study. The protocol for the preliminary interviews was based on the dimensions proposed by Akman \& Yilmaz (2008). The interviews were content-analyzed and confirmed the applicability of the scale. That is, IC is characterized by companies having an innovative organizational culture, internal processes, and the capability of responding to changes in the environment. This general approach for the capability of a firm to innovate is sustained in other studies (e.g., Martínez-Román et al., 2011).

CO was measured with the scale developed by Narver \& Slater (1990). TT was sourced on the measurement developed by Jaworski \& Kohli (1993). FP entailed the most frequently indicators used and reported by Brazilian managers (Sampaio et al., 2011): profit levels, sales volume, and profitability over the last three years when compared to competitors. The following control variables were included: company size (number of employees), organization age, and activity sector (based on SIC). Previous studies found that these control variables have a possible influence on business performance (Atuahene-Gima, 2005). The questionnaire was originally written in English and translated into Portuguese by a bilingual expert. The research instrument was tested among 5 managers with experience in the innovation and 2 academic experts. This procedure allowed refining the measures (Churchill, 1979). The final version of the questionnaire was back-translated into English to verify consistency related to the original version (Craig \& Douglas, 2005). For all measures it was applied a 5 points Likert scale, except for $\mathrm{CO}$ (7 points Likert scale).

\subsection{Data analysis and common method bias}

The research model was tested using partial least squares structural equation modeling (PLS-SEM). PLS-SEM is a technique suitable for small samples and for dependent variables prediction (Leal-Rodríguez, et al., 2014; Lin et al., 2016). Following the PLS-SEM guidelines (e.g., Hair et al., 2013) results were reported using a two-stage approach: the assessment of the measurement model followed by the evaluation of the structural model. The software used was SMARTPLS 3.0.

Common method bias test followed the procedure proposed by Podsakoff et al. (2003). First, different response end-points were used for the main antecedent and consequent variables. Second, Harman's single factor test was conducted with the CFA approach. The model fit indices obtained were very poor. Third, the effects of an unmeasured latent method factor in the empirical model were examined (MacKenzie et al., 1993; Podsakoff et al., 2003). The hypothesized relationships in the model were not affected by the inclusion of a single factor in the structural model. Furthermore, none of the path coefficients between the single source factor and the construct indicators were significant. Therefore, common method variance did not bias the measures.

\subsection{Measurement model}

In order to validate the scale, the following measures were used: factor loadings, tvalues, means, standard deviations, coefficient Alpha, average variance extracted (AVE), composite reliability (CR), and inter-construct correlations (Table 3). Previously, the data normality was verified (for all measured items, skewness was less than 2.0 
and kurtosis less than 7.0; Hair et al., 2013). Overall the results indicate good measurement properties. All item loadings are significant $(p<0.001)$. Inter-construct correlations are low to moderate (0.25-0.66) (Rowntree, 1981). The high coefficient Alpha, AVE scores and CR levels for each construct support the evidence of convergent validity (Hair et al., 2013). To assess discriminant validity, the squared correlation of each factor pair was contrasted with the variance extracted from each factor (Fornell \& Larcker, 1981). In each case, the AVE exceeds the squared correlation between the constructs, providing evidence for discriminant validity.

Table 3. Summary of the scale validation measures.

\begin{tabular}{|c|c|c|}
\hline Item description & $\begin{array}{l}\text { Standardized } \\
\text { Loadings }\end{array}$ & $t$-values \\
\hline \multicolumn{3}{|l|}{ Customer Orientation (Narver \& Slater, 1990) } \\
\hline $\begin{array}{l}\text { - We constantly monitor our level of commitment and } \\
\text { orientation to serving customer needs. }\end{array}$ & 0.808 & 26.327 \\
\hline $\begin{array}{l}\text { - Our business strategies are driven by our beliefs about how } \\
\text { we can create greater value for customers }\end{array}$ & 0.661 & 9.014 \\
\hline $\begin{array}{l}\text { - Our strategy for competitive advantage is based on our } \\
\text { understanding of customer needs }\end{array}$ & 0.720 & 12.603 \\
\hline $\begin{array}{l}\text { - Our strategy for competitive advantage is based on our } \\
\text { understanding of customer needs }\end{array}$ & 0.694 & 15.143 \\
\hline $\begin{array}{l}\text { - We measure customer satisfaction systematically and } \\
\text { frequently. }\end{array}$ & 0.780 & 20.136 \\
\hline - We give close attention to after-sales service. & 0.683 & 10.230 \\
\hline \multicolumn{3}{|l|}{ (scale: $1=$ strongly disagree; $7=$ strongly agree) } \\
\hline \multicolumn{3}{|l|}{ Innovative Capability (Akman \& Yilmaz, 2008) } \\
\hline $\begin{array}{l}\text { - Our firm has an organizational culture and a management } \\
\text { comprehension that support and encourage innovation. }\end{array}$ & 0.809 & 27.873 \\
\hline $\begin{array}{l}\text { - At our firm, knowledge from different resources is used for } \\
\text { product development activities efficiently and rapidly. }\end{array}$ & 0.788 & 19.828 \\
\hline $\begin{array}{l}\text { - Our firm is able to reflect changes at market conditions (such } \\
\text { as changes from customer wants, competitors' products, etc.) } \\
\text { to own products and processes as soon as possible. }\end{array}$ & 0.749 & 16.770 \\
\hline $\begin{array}{l}\text { - Workers of our firm are supported and encouraged to } \\
\text { participate in activities such as product development, } \\
\text { innovation process improvement and to produce new ideas } \\
\text { such topics. }\end{array}$ & 0.676 & 12.406 \\
\hline $\begin{array}{l}\text { - New ideas that come from customers, suppliers, etc. are } \\
\text { evaluated continuously and try to include into product } \\
\text { development activities. }\end{array}$ & 0.686 & 15.329 \\
\hline $\begin{array}{l}\text { - Our firms could be adapted to environmental changes easily } \\
\text { and in the short time by making suitable improvements and } \\
\text { innovations at its products and processes. }\end{array}$ & 0.641 & 11.777 \\
\hline \multicolumn{3}{|l|}{ (scale: $1=$ strongly disagree; 5= strongly agree) } \\
\hline \multicolumn{3}{|l|}{ Technological Turbulence (Jaworski \& Kohli, 1993) } \\
\hline - The technology in our industry is changing rapidly. & 0.833 & 10,871 \\
\hline $\begin{array}{l}\text { - Technological changes provide big opportunities in our } \\
\text { industry. }\end{array}$ & 0.875 & 13.871 \\
\hline $\begin{array}{l}\text { - A large number of new product ideas have been made } \\
\text { possible through technological breakthroughs in our industry. }\end{array}$ & 0.855 & 15.052 \\
\hline - Technological developments in our industry are rather minor* & 0.589 & 4.560 \\
\hline
\end{tabular}


Table 3. Continued...

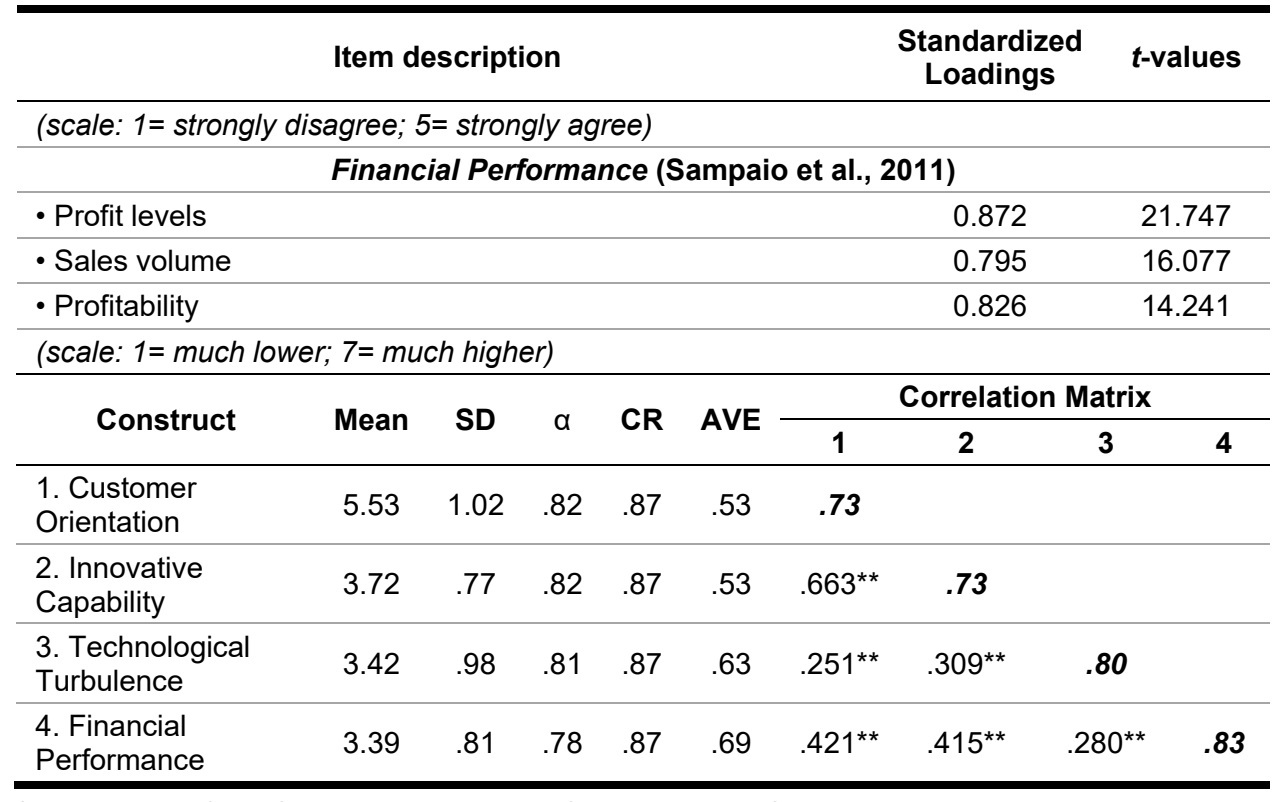

${ }^{*}$ Reverse item. $\mathrm{SD}=$ Standard deviation; $\alpha=$ Cronbach alpha; $\mathrm{CR}=$ composite reliability; AVE = Average variance extracted. Diagonal elements in bold are the square root of AVE. ${ }^{* *} p<0.01$.

\section{Findings}

Path analysis was conducted to test the theoretical framework (Table 4). The bootstrapping procedure (5,000 subsamples) provided the $t$-values and the significance of each path in the model (Hair et al., 2013). Two models were evaluated. First, a simple model (Model 1), with the main relationship between $\mathrm{CO}$ and FP, was verified. In the second model (Model 2 ), the IC was included as a mediating variable in the relationship between $\mathrm{CO}$ and FP. Control variables were incorporated in both models. The explained variances $\left(R^{2}\right)$ of the endogenous variables for each model suggest moderated $R^{2}$ estimates - ranging from 0.231 to 0.439 (Hair et al., 2013). The cross-validated redundancy (Stone-Geisser's $Q^{2}$ ) estimates are greater than 0 for all endogenous constructs in both models, ranging from 0.141 to 0.225 . Due to the possible existence of outward factors or alternatives, the models' predictive relevance is satisfactory (Hair et al., 2013).

Table 4. Structural model results.

\begin{tabular}{|c|c|c|}
\hline \multirow{2}{*}{ Linkages in the model } & \multicolumn{2}{|c|}{ Standardized parameter estimates } \\
\hline & Model 1 & Model 2 \\
\hline \multicolumn{3}{|l|}{ Main effects } \\
\hline $\mathrm{H}_{1}: \mathrm{CO} \rightarrow \mathrm{FP}$ & $0.431^{* * *}(6.071)$ & $0.262^{* *}(2.721)$ \\
\hline $\mathrm{CO} \rightarrow \mathrm{IC}$ & & $0.663^{* * *}(13.785)$ \\
\hline $\mathrm{IC} \rightarrow \mathrm{FP}$ & & $0.257^{* *}(2.710)$ \\
\hline \multicolumn{3}{|l|}{ Control variables } \\
\hline Size $\rightarrow$ FP & $0.147^{*}(2.108)$ & $0.154^{*}(2.105)$ \\
\hline Age $\rightarrow$ FP & $-0.032(0.753)$ & $-0.004(0.094)$ \\
\hline Sector $\rightarrow$ FP & $-0.172^{*}(2.4)$ & $-0.177^{* *}(2.674)$ \\
\hline Indirect effects & & \\
\hline
\end{tabular}




\begin{tabular}{lcc}
\hline \multirow{2}{*}{ Linkages in the model } & \multicolumn{2}{c}{ Standardized parameter estimates } \\
\cline { 2 - 3 } & Model 1 & Model 2 \\
\hline H2: CO $\rightarrow$ IC $\rightarrow$ FP & & $0.171^{* *}(2.266)$ \\
\hline$R^{2}$ & & \\
\hline$I C$ & & 0.439 \\
\hline FP & 0.231 & 0.268 \\
\hline
\end{tabular}

t-values and significance of path coefficients were generated by a bootstrapping procedure $(5,000$ subsamples $) .{ }^{*} p<0.05$. ${ }^{* *} p<0.01$. ${ }^{* *} p<0.001$. Findings suggest that $C O$ has a direct and positive impact on FP. In both models, CO's direct effect on FP is positive and statistically significant $(\beta=0.431$, $p<0.001 ; \beta=0.262, p<0.01$ ). Consequently, $H_{1}$ is supported.

In what concerns the mediating effects, lacobucci et al. (2007, p. 153) suggest that a model with direct and indirect paths should fit simultaneously by structural equation modeling to "estimate either effect while partialling out, or statistically controlling for, the other," even for small samples and models with multiple mediators. The Sobel z-test should also be computed to assess "the relative sizes of the indirect (mediated) vs. direct paths". The mediation effects of a variable M (IC) on the relationship of an independent variable $X(C O)$ and a dependent variable $Y(F P)$ is verified when: $a)$ both $X \rightarrow M$ and $M \rightarrow Y$ paths are significant; and $b$ ) the Sobel z-test for $M$ is also significant. Then, if the direct path $X \rightarrow Y$ is significant, the mediation is reported as "partial"; if not, it is reported as "full". If one (or both) of $\mathrm{X} \rightarrow \mathrm{M}$ and $\mathrm{M} \rightarrow \mathrm{Y}$ paths is (are) non-significant, no mediation can be reported (lacobucci et al., 2007). Findings report that the condition "a" is satisfied as the relationships $\mathrm{CO} \rightarrow \mathrm{IC}(\beta=0.663, p<0.001)$ and IC $\rightarrow$ FP $(\beta=0.257, p<0.01)$ are significant. Condition " $b$ " is also satisfied as the Sobel z-test for the mediating effect of IC in the relationship between $C O$ and FP is significant $(z=2.7496 ; p<0.01)$. Furthermore, the indirect effects of $\mathrm{CO}$ on FP via IC is positive and significant $(\beta=0.171, p<0.01)$. Hence, as the relationship between CO and FP is significant, there is evidence of the partial mediation effect of IC (Model 2). Hence, $\mathrm{H}_{2}$ is supported.

$\mathrm{H}_{3}$ postulates the moderating effect of TT on the indirect effects of $\mathrm{CO}$ on FP. The hypothesis was tested using the PROCESS macro (Hayes, 2015) for moderated mediation modeling. The conditional indirect effect of the independent variable (CO) on the dependent variable (FP) was estimated across a range of low to high values of the moderator (TT) with $95 \%$ confidence bands. Bootstrapping (5,000 samples) with bias correction was used for calculation of standard errors and confidence intervals (Hayes, 2013). This procedure has been frequently applied to check the moderated mediating effects (e.g. Leal-Rodríguez et al., 2014; Wood et al., 2015). Table 5 shows the conditional indirect effects of CO on FP within different levels of TT.

Table 5. Conditional indirect effects of CO on FP within different levels of TT.

\begin{tabular}{ccccc}
\hline \multirow{2}{*}{ TT } & B & Bootstrap SE & \multicolumn{2}{c}{ Bootstrap 95\% CI } \\
\cline { 4 - 5 } & & & Lower & Upper \\
\hline -1 SD (2.435) & 0.018 & 0.043 & -0.066 & 0.111 \\
\hline Mean (3.420) & 0.092 & 0.040 & 0.012 & 0.174 \\
\hline 1 SD (4.400) & 0.200 & 0.065 & 0.081 & 0.337 \\
\hline
\end{tabular}

$\mathrm{B}=$ Unstandardized Regression Coefficient; SE = Standard Error; Cl = Coefficient Interval; SD = Standard Deviation. 
The conditional indirect effects of CO on FP (through IC) among different values $(-1 \mathrm{SD}$, mean, $+1 \mathrm{SD})$ of the moderator TT are further depicted in Figure 2 showing the slopes of the indirect effects for different levels of TT. Concerning the moderating effects, TT interacts positively and significantly with CO on IC $(\beta=0.107 ; p<0.05)$ and with IC $(\beta=0.157 ; p<0.05)$ on FP. The conditional indirect effect of $\mathrm{CO}$ decreases when TT conditions decrease. When TT conditions are one standard deviation (SD) below the mean (2.435), this effect is non-significant (the confidence interval contains zero). When TT conditions are more intense, the mediating effect is significantly stronger. These results support $\mathbf{H 3}$.

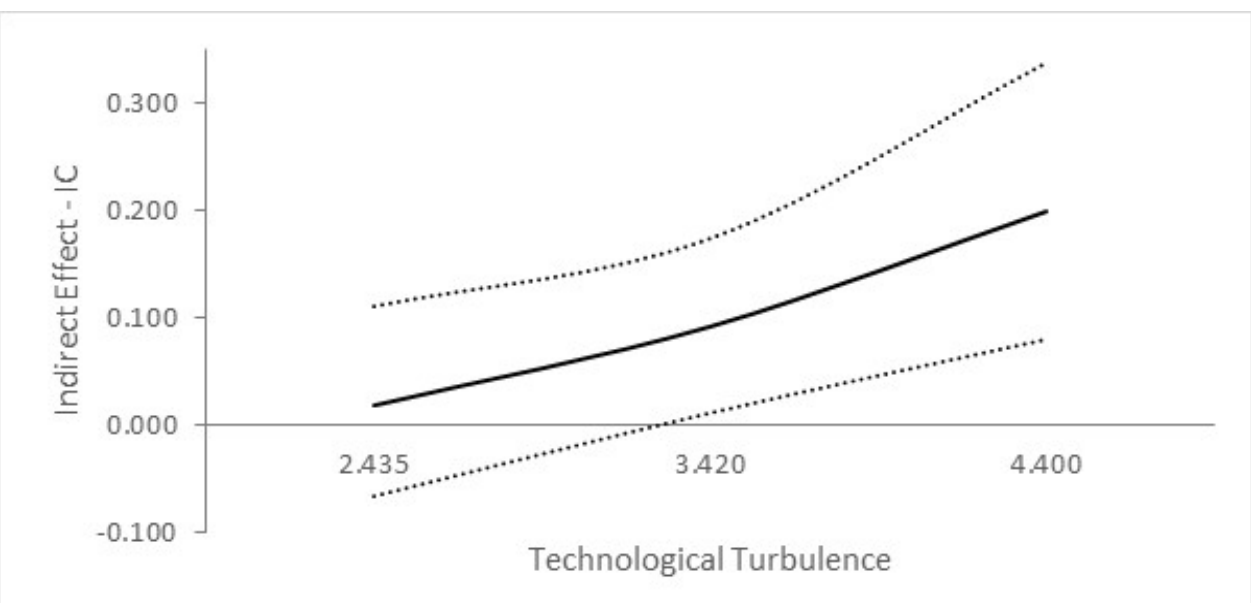

Figure 2. Conditional indirect effects of OC on FP via IC at different TT levels.

\section{Discussion and conclusion}

This study sought to analyze the effect of CO in FP and the role that IC may play in this relationship. The study further considered the environmental variable TT and its effect in the relationships between $\mathrm{CO}, \mathrm{IC}$ and FP. $\mathrm{CO}$ involves the permanent understanding of customer needs and the detailed analysis of how the organization can meet those needs (Augusto \& Coelho, 2009). Companies with high CO proclivity will have in place mechanisms to collect information and generate knowledge about markets. By developing a deep understanding about the market companies will be able to present more successful and adequate offers to consumers. Hence, companies that have a stronger $\mathrm{CO}$ tend to present higher levels of FP. The findings from this study align with previous studies (e.g., Frambach et al., 2016; Cheng \& Krumwiede, 2012; Tajeddini, 2010) by showing a positive direct effect of CO (in isolation) on FP.

Through $\mathrm{CO}$, the organization obtains external environment information that supports the innovation process (Piening \& Salge, 2015), being a source of new ideas, improvements to existing products, and development of new products (Ngo \& O'Cass, 2012; Joshi, 2016). In this sense, CO relates to IC as high levels of CO produce greater knowledge about customer behavior and market potential (Frambach et al., 2016; Wei \& Morgan, 2004). CO also allows the company to take advantage of market opportunities by promoting innovations aligned with customer needs (Saunila et al., 2014) and enables the organization to innovate with greater advantage over competitors (Langerak et al., 2004; Watson et al., 2018). Although, the literature 
explores the issue of capabilities in organizations, the IC construct has not been widely explored in the academic field. Generally speaking, existing studies support the idea that $\mathrm{CO}$ is one of the central factors influencing IC (Joshi, 2016; Cheng \& Krumwiede, 2012; Calantone et al., 2010; Akman \& Yilmaz, 2008). Understanding customers' needs and wants, allow the organization to develop and produce suitable new products (Saunila et al., 2014). Consequently, a customer-oriented culture is core to improve the IC of the firms (Akman \& Yilmaz, 2008). This study expands this idea by including a mediator in the relationship between strategic capabilities and firm performance (Kozlenkova el al., 2013). In what concerns the mediating role of IC in the relationship between $\mathrm{CO}$ and FP, the findings revealed a partial mediation. That is, IC intensifies the effect that $\mathrm{CO}$ has on FP: $\mathrm{CO}$, although important to compete in the market and generate a competitive advantage, ought to be complemented with capabilities that take advantage of market knowledge and information. Different organizational capabilities lead to higher levels of performance (see Watson et al., 2018). As a result, this study posits that a way of transforming knowledge from CO into FP is through IC.

When considering the role of TT in the three-way relationship of $\mathrm{CO}, \mathrm{IC}$ and $\mathrm{FP}$, this study demonstrates that IC acts as a partial mediator in the relationship between $\mathrm{CO}$ and FP in high TT environments. The finding further corroborates that the importance of $\mathrm{CO}$ depends upon environmental conditions. For example, in stable markets with low demand uncertainty, $\mathrm{CO}$ would be irrelevant to enhance innovation performance (Frambach et al., 2016). Conversely, in fast changing environments, IC is likely to be crucial to compete, and is an important requirement specifically in developing countries (Akman \& Yilmaz, 2008). Firms with IC are more successful in dealing with unstable environments, and making innovations that provide superior performance (Piening \& Salge, 2015). This research corroborates such idea by showing the moderation role of TT when IC mediates the relationship between $\mathrm{CO}$ and FP. That is, the stronger the TT, the greater the impact of CO on FP through IC.

\subsection{Managerial implications}

This study has relevant managerial implications for companies intending to integrate $\mathrm{CO}$ and IC into their business. Managers should cultivate strong strategic capabilities, such as, $\mathrm{CO}$ as they have a relevant impact in FP. A strong $\mathrm{CO}$ may be achieved by creating routines into a continuous effort to collect information about customer needs and using that information to develop the most suitable market offers. Organizations will benefit from creating communication channels with customers and from collecting feedback and ideas for their business. Such approach enables companies to better serve the market and, ultimately, be rewarded with higher levels of FP. CO further instills the development of capabilities, such as IC. The underlying idea is that companies with a strong customer-oriented posture collect market information and have a better understanding about customer behavior and needs. Such companies reflect a continuous concern with meeting customer needs and developing their internal procedures and practices accordingly. IC assists the company in taking advantage of the market knowledge through the development of adequate and innovative market offers. IC may be encouraged through the following three pillars: (i) the development of an innovative organizational culture (innovation becomes a shared value among employees and is encouraged by managers); (ii) the creation of innovative internal processes that facilitate innovation and that are reflected in the organizational practices and routines; (iii) the capability to respond to transformations 
in the external environment (which is related to CO). IC allows the company to develop innovations that, if based on market knowledge, will have a higher effect on FP. By combining a strong $\mathrm{CO}$ with IC, managers can magnify the company's performance. This combination results in a sustainable source of competitive advantage.

These capabilities are gradually built and ought to fit the company's business and context. Nonetheless, independently of the company's size or industry, unstable markets are a reality. Managers should also consider that in order to successfully operate in a certain market, there is the need to account for environmental conditions, such as TT. In particular, when operating in high TT environments subject to dynamic markets and technological changes, managers should use IC as a way to bridge and enhance the CO's effect on FP. Companies having a strong IC will be able to better and rapidly adjust to market changes. Hence, developing a strong $\mathrm{CO}$ and IC is core to build competitive advantage.

\subsection{Research limitations and future research}

The study's findings endure limitations and open avenues for future research. The adopted sampling procedure is non-probabilistic limiting the extrapolation of the finding to the population. Nonetheless the selection of the companies in the sample was drawn from a reliable list and the sample had a similar demographical profile to the population. Future research ought to widen the analysis trying to capture nuances amongst the types of industries and other organizational characteristics (e.g., different companies' sizes - micro and large). It would also be relevant to consider multiple respondents in the company to capture the various perspectives into the combination and use of capabilities. This research was conducted in the context of an emerging economy. A replication in other market contexts (e.g., western economies, other emerging economies) is warranted to capture how strategic capabilities interact and behave in distinct business environments and circumstances.

The research model should be further expanded to include other variables and their impact on business performance. For example, it is recommended to explore additional capabilities in order to thoroughly understand alternative paths to the proposed model. Moreover, strategic orientations, such as, entrepreneurial orientation ought to be considered to assess the effect of IC in performance. The metrics for performance may also be expanded to include other measures, such as, non-financial performance and objective measurements. Finally, to better understand the role of environmental conditions in the relationship between capabilities and performance, other moderating environmental variables ought to be considered (e.g., market turbulence).

\section{References}

Akgün, A. E., Keskin, H., \& Byrne, J. C. (2010). Procedural justice climate in new product development teams: antecedents and consequences. Journal of Product Innovation Management, 27(7), 1096-1111. http://dx.doi.org/10.1111/j.1540-5885.2010.00773.x.

Akgün, A. E., Keskin, H., \& Byrne, J. C. (2012). Antecedents and contingent effects of organizational adaptive capability on firm product innovativeness. Journal of Product Innovation Management, 29(S1), 171-189. http://dx.doi.org/10.1111/j.15405885.2012.00949.x. 
Akgün, A. G., Lynn, G. S., \& Byrne, J. C. (2006). Antecedents and consequences of unlearning in new product development teams. Journal of Product Innovation Management, 23(1), 7388. http://dx.doi.org/10.1111/j.1540-5885.2005.00182.x.

Akman, G., \& Yilmaz, C. (2008). Innovative capability, innovation strategy and market orientation: an empirical analysis in Turkish software industry. International Journal of Innovation Management, 12(1), 69-111. http://dx.doi.org/10.1142/S1363919608001923.

Atuahene-Gima, K. (2005). Resolving the capability-rigidity paradox in new product innovation. Journal of Marketing, 69(4), 61-83. http://dx.doi.org/10.1509/jmkg.2005.69.4.61.

Augusto, M., \& Coelho, F. (2009). Market orientation and new-to-the-world products: exploring the moderating effects of innovativeness, competitive strength, and environmental forces. Industrial Marketing Management, 38(1), 94-108. http://dx.doi.org/10.1016/j.indmarman.2007.09.007.

Auh, S., \& Menguc, B. (2005). The influence of top management team functional diversity on strategic orientations: the moderating role of environmental turbulence and inter-functional coordination. International Journal of Research in Marketing, 22(3), 333-350. http://dx.doi.org/10.1016/j.ijresmar.2004.12.003.

Barney, J. B. (1991). Firm resources and sustained competitive advantage. Journal of Management, 17(1), 99-120. http://dx.doi.org/10.1177/014920639101700108.

Baum, J. R., \& Locke, E. A. (2004). The relationship of entrepreneurial traits, skill, and motivation to subsequent venture growth. The Journal of Applied Psychology, 89(4), 587598. http://dx.doi.org/10.1037/0021-9010.89.4.587. PMid:15327346.

Booner, J. (2009). Customer interactivity and new product performance: moderating effects of product newness and product embeddedness. Industrial Marketing Management, 39(3), 485-492. http://dx.doi.org/10.1016/j.indmarman.2008.11.006.

Buganza, T., Dell'era, C., \& Verganti, R. (2009). Exploring the relationships between product development and environmental turbulence: the case of mobile TLC services. Journal of Product Innovation Management, 26(3), 308-321. http://dx.doi.org/10.1111/j.15405885.2009.00660.x.

Calantone, R. J., Garcia, R., \& Dröge, C. (2003). The effects of environmental turbulence on new product development strategy planning. Journal of Product Innovation Management, 20(2), 90-103. http://dx.doi.org/10.1111/1540-5885.2002003.

Calantone, R. J., Harmancioglu, N., \& Droge, C. (2010). Inconclusive innovation "returns": a meta-analysis of research on innovation in new product development. Journal of Product Innovation Management, 27(7), 1065-1081. http://dx.doi.org/10.1111/j.15405885.2010.00771.x.

Cheng, C. C., \& Krumwiede, D. (2012). The role of service innovation in the market orientation: new service performance linkage. Technovation, 32(7-8), 487-497. http://dx.doi.org/10.1016/j.technovation.2012.03.006.

Churchill, G. A., Jr. (1979). A paradigm for developing better measures of marketing constructs. JMR, Journal of Marketing Research, 16(1), 64-73. http://dx.doi.org/10.1177/002224377901600110.

Craig, C. S., \& Douglas, S. P. (2005). International marketing research. Chichester, UK: John Wiley.

Dayan, M., \& Elbanna, S. (2011). Antecedents of team intuition and its impact on the success of new product development projects. Journal of Product Innovation Management, 28(S1), 159-174. http://dx.doi.org/10.1111/j.1540-5885.2011.00868.x.

Deluca, L. M., Verona, G., \& Vicari, S. (2010). Market orientation and R\&D effectiveness in high-technology firms: an empirical investigation in the biotechnology industry. Journal of Product Innovation Management, 27(3), 299-320. http://dx.doi.org/10.1111/j.15405885.2010.00718.x. 
Eisenhardt, K. M., \& Martin, J. Y. (2000). Dynamic capabilities: what are they? Strategic Management Journal, 21(10-11), 1105-1121. http://dx.doi.org/10.1002/10970266(200010/11)21:10/11<1105::AID-SMJ133>3.0.CO;2-E.

Fornell, C., \& Larcker, D. F. (1981). Evaluating structural equation models with unobservable variables and measurement error. JMR, Journal of Marketing Research, 18(1), 39-51. http://dx.doi.org/10.1177/002224378101800104.

Frambach, R. T., Fiss, P. C., \& Ingenbleek, P. T. M. (2016). How important is customer orientation for firm performance? A fuzzy set analysis of orientations, strategies, and environments. Journal of Business Research, 69(4), 1428-1436. http://dx.doi.org/10.1016/j.jbusres.2015.10.120.

Frambach, R. T., Prabhu, J., \& Verhallen, T. M. M. (2003). The influence of business strategy on new product activity: the role of market orientation. International Journal of Research in Marketing, 20(4), 377-397. http://dx.doi.org/10.1016/j.jiresmar.2003.03.003.

Gao, G. Y., Zhou, K. Z., \& Yim, C. K. (2007). On what should firms focus in transitional economies? A study of the contingent value of strategic orientations in China. International Journal of Research in Marketing, 24(1), 3-15. http://dx.doi.org/10.1016/j.jiresmar.2006.09.004.

Garcia, R., \& Calantone, R. (2002). A critical look at technological innovation typology and innovativeness terminology: a literature review. Journal of Product Innovation Management, 19(2), 110-132. http://dx.doi.org/10.1111/1540-5885.1920110.

Grinstein, A. (2008). The effect of market orientation and its components on innovation consequences: a meta-analysis. Journal of the Academy of Marketing Science, 36(2), 166173. http://dx.doi.org/10.1007/s11747-007-0053-1.

Hair, J. F., Jr., Hult, G. T. M., Ringle, C. M., \& Sarstedt, M. (2013). A primer on Partial Least Squares Structural Equation Modeling (PLS-SEM). Thousand Oaks: Sage.

Han, J. K., Kim, N., \& Srivastava, R. (1998). Market orientation and organizational performance: in innovation a missing link? Journal of Marketing, 62(4), 30-45. http://dx.doi.org/10.1177/002224299806200403.

Hayes, A. F. (2013). Introduction to mediation, moderation and conditional process analysis. New York: Guilford Press.

Hayes, A. F. (2015). An index and test of linear moderated mediation. Multivariate Behavioral Research, 50(1), 1-22. http://dx.doi.org/10.1080/00273171.2014.962683. PMid:26609740.

Hooley, G., Greenley, G., Fahy, J., \& Cadogan, J. (2001). Market-focused resources, competitive positioning and firm performance. Journal of Marketing Management, 17(5/6), 503-520. http://dx.doi.org/10.1362/026725701323366908.

Hortinha, P., Lages, C., \& Lages, L. F. (2011). The trade-off between customer and technology orientations: impact on innovation capabilities and export performance. Journal of International Marketing, 19(3), 36-58. http://dx.doi.org/10.1509/jimk.19.3.36.

Hult, G. T. M., Ketchen, D. J., \& Slater, S. F. (2005). Market orientation and performance: an integration of disparate approaches. Strategic Management Journal, 26(12), 1173-1181. http://dx.doi.org/10.1002/smj.494.

lacobucci, D., Saldanha, N., \& Deng, X. (2007). A meditation on mediation: evidence that structural equations models perform better than regressions. Journal of Customer Psychology, 17(2), 140-154. http://dx.doi.org/10.1016/S1057-7408(07)70020-7.

Instituto Brasileiro de Geografia e Estatística - IBGE. (2017). Retrieved in 2018, March 15, from http://www.ibge.gov.br/home/default.php

Jaworski, B. J., \& Kohli, A. K. (1993). Market orientation: antecedents and consequences. Journal of Marketing, 57(3), 53-70. http://dx.doi.org/10.1177/002224299305700304.

Jeong, I., Pae, J. H., \& Zhou, D. (2006). Antecedents and consequences of the strategic orientations in new product development: the case of Chinese manufacturers. Industrial 
Marketing Management, 35(3), 348-358.

http://dx.doi.org/10.1016/j.indmarman.2005.06.010.

Joshi, A. W. (2016). When Does customer orientation hinder (help) radical product innovation? the role of organizational rewards. Journal of Product Innovation Management, 33(4), 435454. http://dx.doi.org/10.1111/jpim.12301.

Kirca, A. H., Jayachandran, S., \& Bearden, W. O. (2005). Market orientation: a meta-analytic review and assessment of its antecedents and impact on performance. Journal of Marketing, 69(2), 24-41. http://dx.doi.org/10.1509/jmkg.69.2.24.60761.

Kozlenkova, I. V., Samaha, S. A., \& Palmatier, R. W. (2013). Resource-based theory in marketing. Journal of the Academy of Marketing Science, 42(1), 1-21. http://dx.doi.org/10.1007/s11747-013-0336-7.

Kuivalainen, O., Sundqvist, S., Puumalainen, K., \& Cadogan, J. W. (2004). The effect of environmental turbulence and leader characteristics on international performance: are knowledge-based firms different? Canadian Journal of Administrative Sciences, 21(1), 3550. http://dx.doi.org/10.1111/j.1936-4490.2004.tb00321.x.

Langerak, F., Hultink, E. J., \& Robben, H. S. J. (2004). The impact of market orientation, product advantage, and launch proficiency on new product performance and organizational performance. Journal of Product Innovation Management, 21(2), 79-94. http://dx.doi.org/10.1111/j.0737-6782.2004.00059.x.

Leal-Rodríguez, A. L., Ariza-Montes, J. A., Roldán, J. L., \& Leal-Millán, A. G. (2014). Absorptive capacity, innovation and cultural barriers: a conditional mediation model. Journal of Business Research, 67(5), 763-768. http://dx.doi.org/10.1016/j.jbusres.2013.11.041.

Lee, R. P. (2010). Extending the environment-strategy-performance framework: the roles of multinational corporation network strength, market responsiveness, and product innovation. Journal of International Marketing, 18(4), 58-73. http://dx.doi.org/10.1509/jimk.18.4.58.

Li, Y., Guo, H., Liu, Y., \& Li, M. (2008). Incentive mechanisms, entrepreneurial orientation, and technology commercialization: evidence from China's transitional economy. Journal of International Marketing, 25(1), 63-78.

Lin, H.-F., Su, J.-Q., \& Higgins, A. (2016). How dynamic capabilities affect adoption of management innovations. Journal of Business Research, 69(2), 862-876. http://dx.doi.org/10.1016/j.jbusres.2015.07.004.

Macintosh, G. (2007). Customer orientation, relationship quality, and relational benefits to the firm. Journal of Services Marketing, 21(3), 150-159. http://dx.doi.org/10.1108/08876040710746516.

MacKenzie, S. B., Podsakoff, P. M., \& Fetter, R. (1993). The impact of organizational citizenship behavior on evaluations of salesperson performance. Journal of Marketing, 57(1), 70-80. http://dx.doi.org/10.1177/002224299305700105.

Martínez-Román, J. A., Gamero, J., \& Tamayo, J. A. (2011). Analysis of innovation in SMEs using an innovative capability-based non-linear model: A study in the province of Seville (Spain). Technovation, 31(9), 459-475. http://dx.doi.org/10.1016/j.technovation.2011.05.005.

Menguc, B., \& Auh, S. (2006). Creating a firm-level dynamic capability through capitalizing on market orientation and innovativeness. Journal of the Academy of Marketing Science, 34(1), 63-73. http://dx.doi.org/10.1177/0092070305281090.

Menguc, B., \& Auh, S. (2010). Development and return on execution of product innovation capabilities: the role of organizational structure. Industrial Marketing Management, 39(5), 820-831. http://dx.doi.org/10.1016/j.indmarman.2009.08.004.

Nakata, C., \& Zhu, Z. (2006). Information Technology and customer orientation: a study of direct, mediated, and interactive linkages. Journal of Marketing Management, 22(3-4), 319354. http://dx.doi.org/10.1362/026725706776861208. 
Narver, J. C., \& Slater, S. F. (1990). The effect of a market orientation on business performance. Journal of Marketing, 54(4), 20-35. http://dx.doi.org/10.1177/002224299005400403.

Neely, A., Filippini, P., Forza, C., Vinelli, A., \& Hii, J. (2001). A framework for analysing business performance, firm innovation and related contextual factors: perceptions of managers and policy makers in two European regions. Integrated Manufacturing Systems, 12(2), 114-124. http://dx.doi.org/10.1108/09576060110384307.

Ngo, L. V., \& O'Cass, A. (2012). In search of innovation and customer-related performance superiority: the role of market orientation, marketing capability, and innovation capability interactions. Journal of Product Innovation Management, 29(5), 861-877. http://dx.doi.org/10.1111/j.1540-5885.2012.00939.x.

Paladino, A. (2008). Analyzing the effects of market and resource orientations on innovative outcomes in times of turbulence. Journal of Product Innovation Management, 25(6), 577592. http://dx.doi.org/10.1111/j.1540-5885.2008.00323.x.

Piening, E. P., \& Salge, T. O. (2015). Understanding the antecedents, contingencies, and performance implications of process innovation: a dynamic capabilities perspective. Journal of Product Innovation Management, 32(1), 80-97. http://dx.doi.org/10.1111/jpim.12225.

Podsakoff, P., MacKenzie, S., Lee, J. Y., \& Podsakoff, N. (2003). Common method bias in behavioral research: A critical review of the literature and recommended remedies. The Journal of Applied Psychology, 15(2), 879-903. http://dx.doi.org/10.1037/00219010.88.5.879. PMid:14516251.

Rijsdijk, S. A., Langerak, F., \& Jan Hultink, E. (2010). Understanding a two-sided coin: antecedents and consequences of a decomposed product advantage. Journal of Product Innovation Management, 28(1), 33-47. http://dx.doi.org/10.1111/j.1540-5885.2010.00779.x.

Rowntree, D. (1981). Statistics without tears. New York: Penguin Books.

Sampaio, C. H., Simões, C., Perin, M. G., \& Almeida, A. (2011). Marketing metrics: insights from Brazilian managers. Industrial Marketing Management, 40(1), 8-16. http://dx.doi.org/10.1016/j.indmarman.2010.09.005.

Sanches, P. L. B., \& Machado, A. G. C. (2014). Innovation strategies from the resource-based view perspective: analysis and evidences in technology-based companies. Gestão \& Produção, 21(1), 125-145. http://dx.doi.org/10.1590/S0104-530X2014005000005.

Saunila, M., Ukko, J., \& Rantanen, H. (2014). Does innovation capability really matter for the profitability of SMEs? Knowledge and Process Management, 21(2), 134-142. http://dx.doi.org/10.1002/kpm.1442.

Sher, P. J., \& Yang, P. Y. (2005). The effects of innovative capabilities and R\&D clustering on firm performance: the evidence of Taiwan's semiconductor industry. Technovation, 25(1), 33-43. http://dx.doi.org/10.1016/S0166-4972(03)00068-3.

Smirnova, M., Naudé, P., Henneberg, S. C., Mouzas, S., \& Kouchtch, S. P. (2011). The impact of market orientation on the development of relational capabilities and performance outcomes: the case of Russian industrial firms. Industrial Marketing Management, 40(1), 44-53. http://dx.doi.org/10.1016/j.indmarman.2010.09.009.

Sok, P., O'Cass, A., \& Miles, M. P. (2016). The performance advantages for SMEs of product innovation and marketing resource: capability complementarity in emerging economies. Journal of Small Business Management, 54(3), 805-826. http://dx.doi.org/10.1111/jsbm.12172.

Song, M., Droge, C., Hanvanich, S., \& Calantone, R. (2005). Marketing and technology resource complementarity: an analysis of their interaction effect in two environmental contexts. Strategic Management Journal, 26(3), 259-276. http://dx.doi.org/10.1002/smj.450.

Sousa, C. M. P., \& Lengler, J. (2009). Psychic distance, marketing strategy and performance in export ventures of brazilian firms. Journal of Marketing Management, 25(5/6), 591-610. http://dx.doi.org/10.1362/026725709X461876. 
Spanjol, J., Qualls, W. J., \& Rosa, J. A. (2011). How many and what kind? The role of strategic orientation in new product ideation. Journal of Product Innovation Management, 28(2), 236250. http://dx.doi.org/10.1111/j.1540-5885.2010.00794.x.

Stock, R. M., \& Zacharias, N. A. (2011). Patterns and performance outcomes of innovation orientation. Journal of the Academy of Marketing Science, 39(6), 870-888. http://dx.doi.org/10.1007/s11747-010-0225-2.

Tajeddini, K. (2010). Effect of customer orientation and entrepreneurial orientation on innovativeness: evidence from the hotel industry in Switzerland. Tourism Management, 31(2), 221-231. http://dx.doi.org/10.1016/j.tourman.2009.02.013.

Teece, D. (2007). Explicating dynamic capabilities: the nature and microfoundations of (sustainable) enterprise performance. Strategic Management Journal, 28(13), 1319-1350. http://dx.doi.org/10.1002/smj.640.

Theoharakis, V., \& Hooley, G. J. (2008). Customer orientation and innovativeness: differing roles in new and old Europe. International Journal of Research in Marketing, 25(1), 69-79. http://dx.doi.org/10.1016/j.jiresmar.2007.09.007.

Van Riel, A. C. R., Lemmink, J., \& Ouwersloot, H. (2004). High-technology service innovation success: a decision-making perspective. Journal of Product Innovation Management, 21(5), 348-359. http://dx.doi.org/10.1111/j.0737-6782.2004.00087.x.

Vargas, S. M. L., Gonçalo, C. R., Ribeirete, F., \& Souza, Y. S. (2017). Organizational practices required for innovation: a study in an information technology company. Gestão \& Produção, 24(2), 221-235. http://dx.doi.org/10.1590/0104-530x2161-16.

Vorhies, D. W., Morgan, R. E., \& Autry, C. W. (2009). Product-market strategy and the marketing capabilities of the firm: impact on market effectiveness and cash flow performance. Strategic Management Journal, 30(12), 1310-1334. http://dx.doi.org/10.1002/smj.798.

Watson, R., Wilson, H. N., Smart, P., \& Macdonald, E. K. (2018). Harnessing difference: a capability-based framework for stakeholder engagement in environmental innovation. Journal of Product Innovation Management, 35(2), 254-279. http://dx.doi.org/10.1111/jpim.12394.

Wei, Y. S., \& Morgan, N. A. (2004). Supportiveness of organizational climate, market orientation, and new product performance in chinese firms. Journal of Product Innovation Management, 21(6), 375-388. http://dx.doi.org/10.1111/j.0737-6782.2004.00092.x.

Wood, M. S., Bradley, S. W., \& Artz, K. (2015). Roots, reasons, and resources: situated optimism and firm growth in subsistence economies. Journal of Business Research, 68(1), 127-136. http://dx.doi.org/10.1016/j.jbusres.2014.04.008.

Woodside, A. G. (2005). Firm orientations, innovativeness, and business performance: advancing a system dynamics view following a comment on Hult, Hurley, and Knight's 2004 study. Industrial Marketing Management, 34(3), 275-279. http://dx.doi.org/10.1016/j.indmarman.2004.10.001.

Yang, Y., Wang, Q., Zhu, H., \& Wu, G. (2012). What are the effective strategic orientations for new product success under different environments? An empirical study of chinese businesses. Journal of Product Innovation Management, 29(2), 166-179. http://dx.doi.org/10.1111/j.1540-5885.2011.00900.x.

Yilmaz, C., Alpkan, L., \& Ergun, E. (2005). Cultural determinants of customer- and learningoriented value systems and their joint effects on firm performance. Journal of Business Research, 58(10), 1340-1352. http://dx.doi.org/10.1016/j.jbusres.2004.06.002. 